\title{
Markers of angiogenesis (CD31, CD34, rCBV) and their prognostic value in low-grade gliomas
}

\section{Markery angiogenezy (CD31, CD34, rCBV) w utkaniu wysoko zróżnicowanych glejaków mózgu oraz ich wartość rokownicza}

\author{
Krzysztof Majchrzak', Wojciech Kaspera', Janusz Szymaś2, Barbara Bobek-Billewizz ${ }^{3}$, Anna Hebda ${ }^{3}$, Henryk Maichrzak' \\ IKatedra i Oddział Kliniczny Neurochirurgii w Sosnowcu Śląskiego Uniwersytetu Medycznego w Katowicach \\ 2Katedra i Zakład Patomorfologii Klinicznej Uniwersytetu Medycznego w Poznaniu \\ ${ }^{3}$ Zakład Radiodiagnostyki Centrum Onkologii - Instyłutu im. M. Skłodowskiej-Curie Oddział w Gliwicach
}

Neurologia i Neurochirurgia Polska 2013; 47, 4: 325-331

DOI: 10.5114/ninp.2013.36757

\begin{abstract}
Background and purpose: Antigens CD31 and CD34 and relative cerebral blood volume ( $\mathrm{rCBV}$ ) in gliomas reflect in different ways neoangiogenesis of the tumour. Thus, we decided: (1) to estimate the correlation between the values of CD31 and CD34 and the value of rCBV in low-grade gliomas (LGG), and (2) to establish the prognostic value of these markers.

Material and methods: The investigated group consisted of 53 patients with LGG who were operated on in the Neurosurgical Department at Sosnowiec between 2005 and 2011. On the basis of perfusion-weighted imaging (PWI-MRI) in the tumour texture, $\mathrm{rCBV}$ was calculated. The values of $\mathrm{CD} 31$ and CD34 were estimated on the basis of immunohistochemical investigation. Three outcome measures were assessed: (1) overall survival, (2) progression-free survival, and (3) malignant-free survival. Statistical analyses were done using the STATISTICA 9.0 program.

Results: Higher value of $\mathrm{rCBV}$ in the texture of LGG significantly correlated with higher CD31 $(p=0.0006)$ and CD34 values ( $p=0.0043$ ). Progression-free survival was significantly longer in patients with $\mathrm{rCBV}<1.75$ than for persons with $\mathrm{rCBV}>1.75(p=0.015)$. Lower expression of CD31 correlated with probability of longer survival of the patients after the operation of LGG $(p=0.068)$.
\end{abstract}

\section{Streszczenie}

Wstęp i cel pracy: Antygeny CD31 i CD34 oraz wartość względnej objętości krwi (rCBV) w tkance glejaków mózgu odzwierciedlają w różnym stopniu neoangiogenezę w obrębie guza. Dlatego autorzy postanowili określić korelację między wartościami CD31 i CD34 a wartością rCBV w utkaniu glejaków wysoko zróżnicowanych oraz ustalić wartość rokowniczą tych wskaźników.

Materiał i metody: Badania dotyczyły 53 pacjentów, którzy w latach 2005-2011 byli operowani w Klinice Neurochirurgii w Sosnowcu z powodu wysoko zróżnicowanego glejaka mózgu. U chorych tych na podstawie badania perfuzji metodą rezonansu magnetycznego określono objętość krwi w guzie przed operacją (rCBV). Wartości CD31 i CD34 oznaczono na podstawie reakcji immunohistochemicznej. Miarami wykorzystanymi w rokowaniu były: 1) całkowity czas przeżycia, 2) progresja nowotworu i 3) złośliwa transformacja nowotworu. Analizę statystyczną wykonano za pomocą programu STATISTICA 9.0.

Wyniki: Większe wartości rCBV w utkaniu glejaka wysoko zróżnicowanego istotnie korelowały z większymi wartościami CD31 $(p=0,0006)$ i CD34 ( $p=0,0043)$. Czas wolny od progresji nowotworu (PFS) był istotnie dłuższy u chorych $\mathrm{z}$ wartością rCBV w utkaniu glejaka $<1,75$ niż u osób $\mathrm{z}$ war-

Correspondence address: Wojciech Kaspera, Katedra i Oddział Kliniczny Neurochirurgii, Plac Medyków 1, 41-200 Sosnowiec, tel. +48 3236825 51, e-mail:wkaspera@wp.pl

Received: 3.02.2012; accepted: 10.07.2012 
Conclusions: Density of microvessels as assessed immunohistochemically with CD31+ and CD34+ in LGG correlated with the value of $\mathrm{rCBV}$ in the tumour. The value of 1.75 for $\mathrm{rCBV}$ may be the threshold for better or poorer outcome of these patients. Expression of CD31 antigen is an important prognostic factor for the time of survival for patients with LGG.

Key words: low-grade gliomas, outcome, CD31, CD34, rCBV.

\section{Introduction}

CD31 and CD34 molecules constitute markers for vascular endothelium; moreover, CD34 is a marker for bone marrow stem cells within the circulatory system $[1,2]$. Their expression has been found in glioma cells as well [2]. Khattab et al. proved the presence of CD31 antigen in $78 \%$ of brain gliomas. The level of expression increased with the level of malignancy of the tumour [3]. The highest levels of expression have been reported in glioblastomas, then in anaplastic, gemistocytic and, finally, fibrillary astrocytomas. Similar findings were reported by others [4]. Circulatory bone marrow stem cells that show high expression of CD34 antigen are incorporated into glioma vessels and expand in their vicinity [5].

The highest expression levels of CD31 and CD34 antigens are usually found within neoangiogenic zones of an expanding brain tumour. Angiogenesis within a brain tumour is reflected in magnetic resonance imaging (MRI) by maps of relative cerebral blood volume ( $\mathrm{rCBV}$ ) and relative cerebral blood flow (rCBF) generated with a dynamic susceptibility contrast-enhanced perfusion-weighted imaging (DSCE-PWI) sequence. Importantly, rCBV positively correlates with biological malignancy of glioma and vascular density [6-9]. Relative cerebral blood volume values are the lowest within astrocytomas, higher within oligoastrocytomas, and the highest within oligodendrogliomas [10]. Accordingly, rCBV values allow the differentiation of glioma subtypes.

Based on aforementioned data, we decided to perform a prospective study with 68 participants treated for low-grade brain gliomas [11] in order to evaluate the expression levels of endothelial markers CD31 and CD34 along with their prognostic values. Prognostic tością $\mathrm{rCBV}>1,75(p=0,015)$. Niskie wartości antygenu CD31 korelują z prawdopodobieństwem dłuższego przeżycia chorych z wysoko zróżnicowanymi glejakami $(p=0,068)$.

Wnioski: Gęstość mikronaczyń wyznakowanych immunohistochemicznie CD31 + i CD34+ w utkaniu wysoko zróżnicowanych glejaków koreluje $\mathrm{z}$ wielkością rCBV w obrębie tych guzów. Wartość 1,75 dla rCBV w glejakach wysoko zróżnicowanych może być wartością progową dla lepszego i gorszego rokowania tych pacjentów. Ekspresja antygenu CD31 jest ważnym czynnikiem rokowniczym czasu przeżycia chorych z wysoko zróżnicowanymi glejakami mózgu.

Słowa kluczowe: glejaki wysoko zróżnicowane, rokowanie, CD31, CD34, rCBV.

value of $\mathrm{rCBV}$ within the tumour was appraised as well. Finally, CD31 and CD34 expression levels were correlated with $\mathrm{rCBV}$ values within the tumour.

\section{Material and methods}

Our cohort included 53 patients out of 68 who were treated for low-grade gliomas in the Department of Neurosurgery, Silesian Medical University in Sosnowiec between 2005 and 2011. All of them had perfusionweighted MR imaging (PW-MRI) performed prior to surgery in order to assess $\mathrm{rCBV}$ within the tumour. Magnetic resonance studies were performed either on $1.5 \mathrm{~T}$ Magnetom Avanto (Siemens AG, Erlangen, Germany) or 3 T Achieva (Philips Medical Systems, Best, Netherland) scanners with standard head coils. A fast echo-planar imaging (EPI) sequence during and after paramagnetic contrast injection was implemented so as to acquire PWI data. Settings for perfusion studies were as follows: repetition time/echo time (TR/TE) 1560/30 ms, field of view $(\mathrm{FOV}) 250 \times 250 \mathrm{~mm}, 21$ slices (thickness $5 \mathrm{~mm}$ ), matrix $128 \times 128$, voxel size $2.0 \times 2.0$, gap $20 \%$, flip angle $90^{\circ}$ and acquisition time $1 \mathrm{~min} 24 \mathrm{~s}$ with 50 repetitions of $1.6 \mathrm{~s}$ for the Siemens Avanto scanner and TR/TE 16/24 ms, FOV $230 \times 187 \times 144$ mm, 36 slices (thickness $-4 \mathrm{~mm}$ ), matrix $64 \times 52$, voxel size $3.59 \times$ 3.59 , flip angle $7^{\circ}$ and acquisition time $1 \mathrm{~min} 28 \mathrm{~s}$ with 60 repetitions of $1.4 \mathrm{~s}$ for the Philips Achieva scanner. Paramagnetic contrast $(0.1 \mathrm{mmol} / \mathrm{kg})$ was injected at $6 \mathrm{~mL} / \mathrm{s}$ following the $4^{\text {th }}$ acquisition with subsequent saline bolus. The standard manufacturer's software was subsequently used in order to analyse PWI data. Next, colourcoded rCBV maps were used to define regions of interest (ROIs). Regions of interest were placed within solid parts of the tumours and in the contralateral hemisphere's nor- 
mal white matter as a reference. The relationship between mean $\mathrm{rCBV}$ within the tumour and $\mathrm{rCBV}$ value within normal white matter was then calculated based on those predefined ROIs (normalized rCBV).

Prognosis was defined as: (1) overall survival (OS) - from surgery to death; (2) progression-free survival (PFS) - from surgery to either tumour enlargement in the FLAIR sequence or the occurrence of contrast enhancement, and (3) malignant transformation-free survival (MFS) - from surgery to malignant transformation affirmed on MRI and confirmed with a biopsy or open surgery.

A routine microscopic examination of postoperative sections of the tumour served as a basis for histopathological diagnosis. Expression of endothelial markers CD31 and CD34 was subsequently identified and scored within the parenchyma of the glial tumour.

Tissue samples for histopathology were fixed for 16 hours in $4 \%$ buffered formalin then dehydrated and embedded in Histowax (HistoLab). Next, 3-4 $\mu$ m thick paraffin sections were sectioned on a rotatory microtome and mounted on Superfrost Plus (Menzel Gläser) glasses. Sections were then dried, deparaffinized in PTlink (Dako) tissue processor, processed with EnVision ${ }^{\mathrm{TM}}$ FLEX Target Retrieval Solution (Dako) and gradually hydrated. Endogenous peroxidase activity was subsequently quenched with hydrogen peroxidase (EnVision $^{\text {тм }}$ FLEX Peroxidase-Blocking Reagent, Dako).

All immunohistochemical reactions were performed at the same time for all of the samples in the Neu tissue processor. Commercially available antibodies (FLEX Ready-to-Use Primary Antibodies, DAKO) were used in order to detect the markers in question: FLEX MO A-HU CD31, ENDOTHELIAL CELL, clone JC70A for the CD31 marker and FLEX MO A-HU CD34 CLASS II, clone QBEnd 10Autostainer Link 48 for the CD34 marker along with the visualization system EnVisionTM FLEX+ (DAKO). 3,3'-diaminobenzidine served as a chromogen. Afterwards, immunohistochemistry data were evaluated with an Axioplan 2e light microscope equipped with an Axiocam HRc digital camera and image analysis software Axiovision 4.3 (Zeiss). Primary analysis of the sample under small magnification allowed the selection of hot spots with the richest vascularisation. Then the selected region was studied for the presence of a positive immunohistochemical reaction under $400 \times$ magnification. Criteria for microscopic analysis of CD31 and C34 expression were as follows:

A single, positively stained endothelial cell or a cluster of them regardless of the presence of the lumen was considered a vessel. A semi-quantitative, three-step scale for evaluation of microvascular density was implemented for 20 consecutive fields of view and the average was then calculated:

$1+$ (scant), i.e. $<20$ vessels within a field of view, $2+$ (moderate), i.e. 20-100 vessels within a field of view, $3+$ (intense), i.e. $>100$ vessels within a field of view.

\section{Statistical analysis}

Statistical analysis was performed with STATISTICA 9.0 software. In order to assess the differences between variables, a non-parametric Kruskal-Wallis ANOVA was initially implemented. Whenever a statistically significant difference was found, multiple comparisons were performed. Kaplan-Meier analysis was performed for OS, PFS and MFS and a log-rank test was subsequently executed in order to evaluate the influence of analysed variables on survival measurements (OS, PFS and MFS).

\section{Results}

CD31 and CD34 expression levels along with rCBV values are presented in Table 1.

CD31 expression levels were determined at $1+$ in 19 cases, $2+$ in 26 cases and $3+$ in 8 cases.

CD34 expression levels were determined at $1+$ in 24 cases, $2+$ in 21 cases and $3+$ in 8 cases.

Relative CBV values were calculated for 49 patients (4 patients were not included) and varied from 0.52 to 4.39. Examples of lowest and highest $\mathrm{rCBV}$ values are shown on perfusion maps along with standard MRI images (Figs. 1A-B and Figs. 2A-B).

Consequently, rCBV values were compared in subgroups of patients with various expressions of CD31 and CD34 antigens. Analysis was performed with non-parametric Kruskal-Wallis test with multiple comparisons of rCBV values in different CD31 and CD34 expression subgroups. Results are presented in Table 2.

Relative $\mathrm{CBV}$ values in tissue that showed various CD31 and CD34 expression levels from $1+$ to $3+$ were significantly different. The higher the expression levels, the higher was the $\mathrm{rCBV}$ within the tumour.

Relative CBV values in relation to CD31 expression levels differed significantly $(p=0.0006)$. Multiple comparisons for CD31 showed significant differences of $\mathrm{rCBV}$ values between $1+$ and $3+\operatorname{subgroups}(p=$ $0.0004)$ as well as between $2+$ and $3+\operatorname{subgroups}(p=$ $0.0402)$. The relative $\mathrm{CBV}$ value in the subgroup of 
Table 1. CD31 and CD34 expression levels and relative cerebral blood volume (rCBV) values measured within the parenchyma of low-grade gliomas

\begin{tabular}{|c|c|c|c|}
\hline No. & CD31 & CD34 & rCBV \\
\hline 1. & $2+$ & $1+$ & 1.27 \\
\hline 2. & $2+$ & $2+$ & 1.51 \\
\hline 3. & $2+$ & $1+$ & 2.78 \\
\hline 4. & $2+$ & $1+$ & 1.11 \\
\hline 5. & $2+$ & $2+$ & 1.58 \\
\hline 6. & $3+$ & $3+$ & 1.49 \\
\hline 7. & $1+$ & $2+$ & 1.27 \\
\hline 8. & $3+$ & $3+$ & 1.68 \\
\hline 9. & $2+$ & $2+$ & 1.73 \\
\hline 10 & $1+$ & $1+$ & 1.29 \\
\hline 11. & $2+$ & $2+$ & \\
\hline 12 & $2+$ & $2+$ & 0.87 \\
\hline 13. & $3+$ & $2+$ & 1.88 \\
\hline 14. & $1+$ & $1+$ & 1.68 \\
\hline 15. & $2+$ & $1+$ & 1.62 \\
\hline 16. & $1+$ & $1+$ & 0.91 \\
\hline 17. & $2+$ & $2+$ & 1.52 \\
\hline 18. & $3+$ & $3+$ & 4.39 \\
\hline 19. & $2+$ & $2+$ & 0.79 \\
\hline 20 & $2+$ & $2+$ & 1.60 \\
\hline 21. & $1+$ & $1+$ & 0.61 \\
\hline 22 & $1+$ & $1+$ & 0.62 \\
\hline 23. & $1+$ & $1+$ & 2.45 \\
\hline 24 & $1+$ & $1+$ & 0.99 \\
\hline 25 & $3+$ & $3+$ & 2.08 \\
\hline 26 & $1+$ & $1+$ & 1.10 \\
\hline 27. & $2+$ & $3+$ & \\
\hline 28 & $2+$ & $2+$ & 1.37 \\
\hline 29. & $1+$ & $1+$ & 0.72 \\
\hline 30. & $1+$ & $1+$ & 1.00 \\
\hline 31. & $2+$ & $2+$ & 0.93 \\
\hline 32. & $2+$ & $3+$ & 1.94 \\
\hline 33. & $2+$ & $1+$ & 1.83 \\
\hline 34. & $2+$ & $2+$ & 1.28 \\
\hline 35 & $2+$ & $3+$ & \\
\hline 36. & $3+$ & $3+$ & 3.12 \\
\hline
\end{tabular}

\begin{tabular}{|c|c|c|c|}
\hline No. & CD31 & CD34 & rCBV \\
\hline 37. & $2+$ & $2+$ & 1.96 \\
\hline 38. & $1+$ & $1+$ & 1.08 \\
\hline 39. & $3+$ & $2+$ & 2.99 \\
\hline 40 & $2+$ & $1+$ & 1.50 \\
\hline 41 & $1+$ & $1+$ & 1.84 \\
\hline 42 & $1+$ & $2+$ & 2.40 \\
\hline 43 & $3+$ & $3+$ & 3.63 \\
\hline 44. & $1+$ & $1+$ & 0.81 \\
\hline 45 & $2+$ & $2+$ & 1.19 \\
\hline 46. & $2+$ & $1+$ & \\
\hline 47. & $1+$ & $1+$ & 0.78 \\
\hline 48 & $1+$ & $1+$ & 0.52 \\
\hline 49. & $2+$ & $1+$ & 1.26 \\
\hline 50 & $1+$ & $2+$ & 0.87 \\
\hline 51. & $1+$ & $1+$ & 2.62 \\
\hline 52. & $2+$ & $2+$ & 1.37 \\
\hline 53. & $2+$ & $2+$ & 2.76 \\
\hline
\end{tabular}

patients with tumours assessed at $3+$ was considerably the highest.

Similarly, rCBV values in relation to CD34 expression levels differed significantly $(p=0.0043)$ as well. Multiple comparisons for CD34 showed significant differences of average rCBV values between $1+$ and $3+$ subgroups $(p=0.0032)$. Relative $\mathrm{CBV}$ values in the subgroup with $3+$ CD34 expression levels were significantly higher than in the subgroup with $1+$ expression. No significant differences in $\mathrm{rCBV}$ values between the tumours with $2+$ and $3+$ expression levels were found.

Previous studies $[11,12]$ proved that an $\mathrm{rCBV}$ value of 1.75 within a low-grade glial tumour is a threshold value for better or worse prognosis of patients. Based on that, we decided to evaluate the prognosis for patients with $\mathrm{rCBV}$ values $<$ and $\geq 1.75$.

Log-rank analysis proved significant differences of PFS between patients with $\mathrm{rCBV}$ values $<1.75$ and $\geq 1.75$ ( $p=0.015$ ) (Fig. 3).

In order to evaluate the risk of recurrence/progression of the tumour based on $\mathrm{rCBV}$ values in our cohort of 53 patients we assessed the optimal, mean value of $\mathrm{rCBV}$ based on the ROC curve first. The obtained value, however, had 

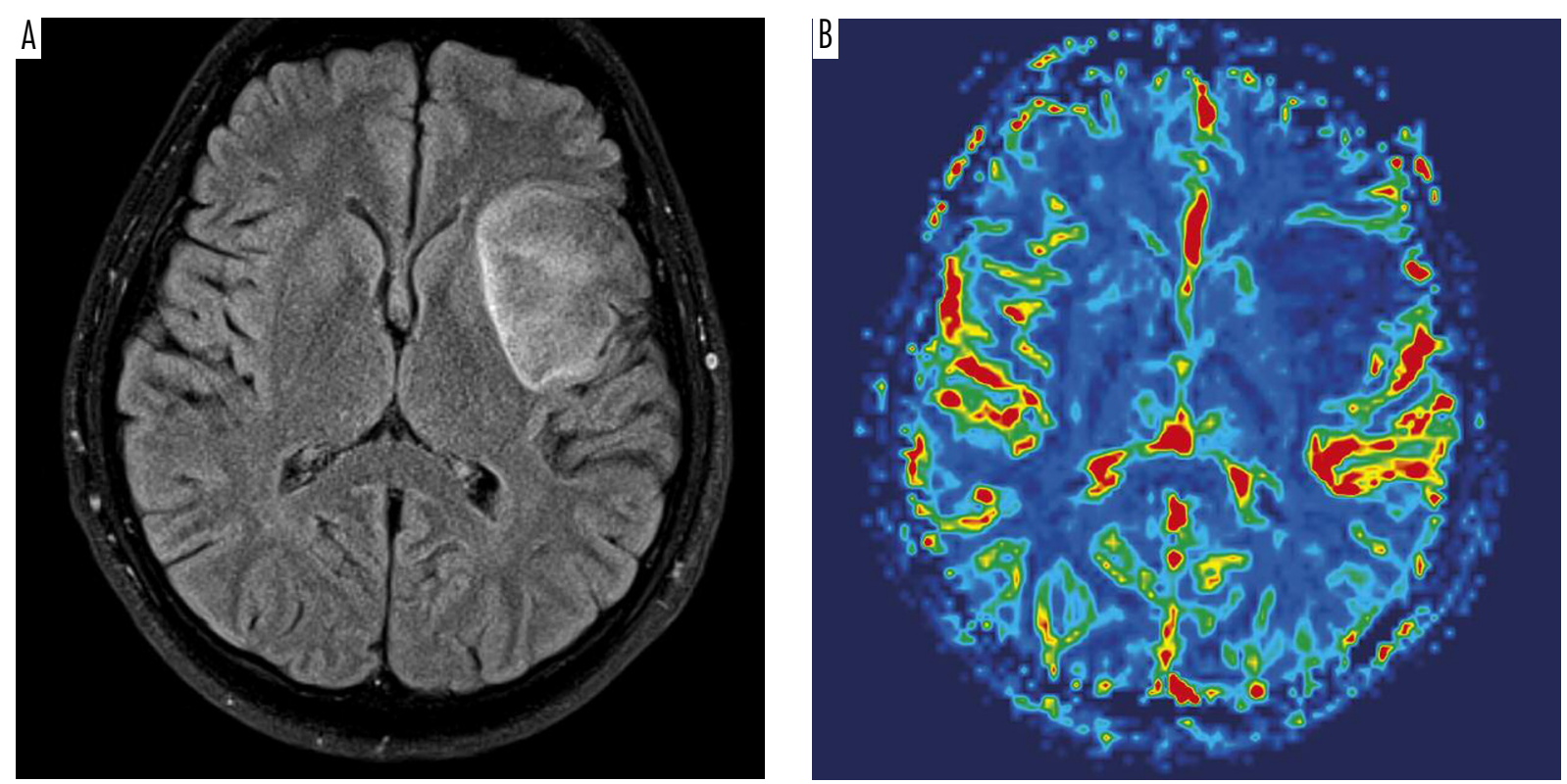

Fig. 1A-B. Perfusion map of a patient with an insular glioma with the lowest relative cerebral blood volume value

Table 2. Comparison of relative cerebral blood volume (rCBV) values in tissues showing CD31 and CD34 expression

\begin{tabular}{|c|c|c|c|c|}
\hline CD31 expression & $1+$ & $2+$ & $3+$ & p-value* \\
\hline \multicolumn{5}{|l|}{$\mathrm{rCBV}$} \\
\hline median (interquartile range) & $1.00(0.78-1.68)$ & $1.51(1.26-1.73)$ & $2.54(1.78-3.38)$ & \multirow[t]{2}{*}{0.0006} \\
\hline range & $0.61-2.45$ & $0.79-2.78$ & $1.49-4.39$ & \\
\hline CD34 expression & $1+$ & $2+$ & $3+$ & p-value* \\
\hline \multicolumn{5}{|l|}{$\mathrm{rCBV}$} \\
\hline median (interquartile range) & $1.11(0.81-1.68)$ & $1.51(1.23-1.92)$ & $2.09(1.68-3.63)$ & \multirow[t]{2}{*}{0.0043} \\
\hline range & $0.61-2.78$ & $0.79-2.99$ & $1.49-4.39$ & \\
\hline
\end{tabular}

*Kruskal-Wallis test

neither high sensitivity nor high specificity and the area under the curve presented low accuracy of classification.

Accordingly, an analysis of overall survival (OS) relative to the different expression levels of CD31 antigen was performed. Results are presented in Figure 4.

The differences between the curves were assessed with the log-rank test. For overall survival of 53 patients with CD31 expression, a $p$-value of 0.0683 was achieved. This value is marginally significant. Values for PFS and MFS were not significant. For CD34, the $p$-value averaged 0.3173 for overall survival, i.e. was not significant.

\section{Discussion}

Malignant, rapidly growing glial tumours - glioblastoma multiforme in particular - are characterized by high intensity of neoangiogenesis and rapid growth of the tumour [13].

In order to evaluate the intensity of angiogenesis, we performed studies with anti-CD31 and anti-CD34 antibodies. They can detect antigens on the surface of endothelial cells of microvessels within the tumour $[4,14]$. Immunohistochemical stains for CD31 and CD34 markers allow the assessment of vascular density within the tumour as well as in the regions free of neoplastic infiltration [15]. Based on microvascular density within the tumour evaluated with CD31 antibody it was proven that glioblastomas have the most intense expansion of microvessels, while in oligodendrogliomas or WHO grade II astrocytomas it is either moderate or scant $[4,14,16,17]$. Our study of low-grade gliomas, on the other hand, showed that microvascular density, judged based on CD31 and CD34 presence within 

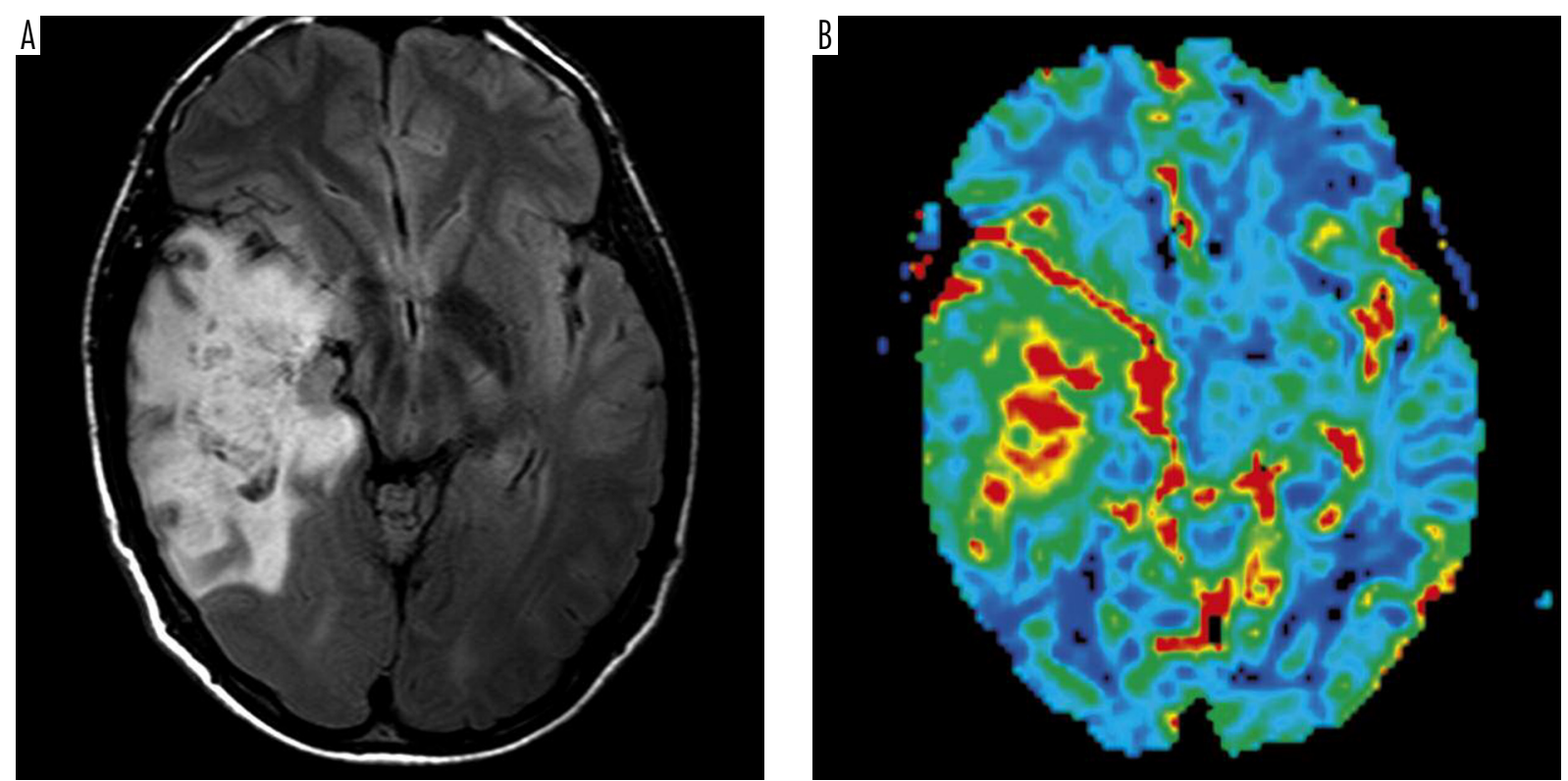

Fig. 2A-B. Perfusion map of a patient with an insular glioma with temporal lobe involvement and the highest relative cerebral blood volume value

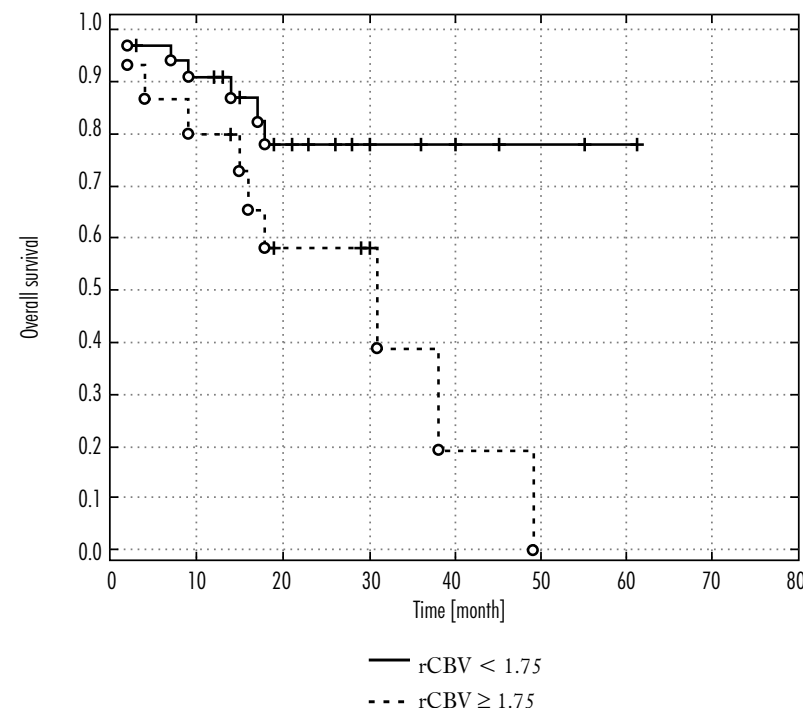

Fig. 3. Progression-free survival of patients with relative cerebral blood volume (rCBV) values $<$ or $\geq 1.75$

endothelial cells of low-grade gliomas, varies considerably from scant to intense. It suggests that a fraction of low-grade glial tumours has a substantial number of pathological vessels that might support more robust expansion of a tumour. Angiogenesis within the tumour might be stimulated by bone marrow stem cells or result from stimulatory effects of glioma cells on this cell population. Santarelli et al. [5] reported that endothelial progenitor cells derived from bone marrow stem cells

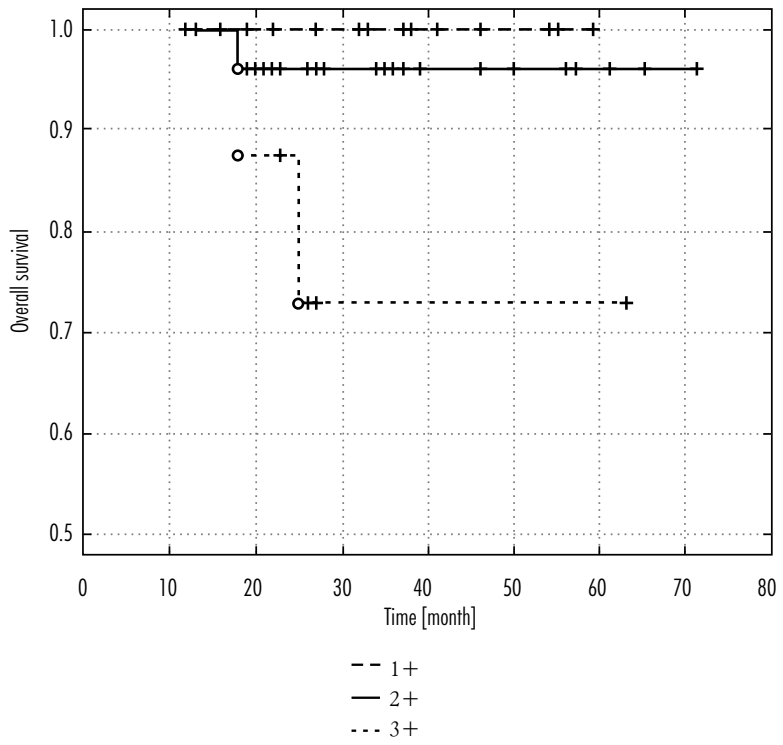

Fig. 4. Kaplan-Meier curves for overall survival of the patients based on CD31 expression

might be integrated into new blood vessels within the developing malignant glioma. Importantly, these cells express CD34 and Flk-1. While the percentage of bone marrow-derived cells within the glioma is relatively low (4\%), they are usually found within ramifications or at the end of newly born vessels, i.e. they decide about the further development of glioma vessels.

Whenever CD31 and CD34 values are related to the $\mathrm{rCBV}$ within the tumour it has been proven that $\mathrm{CD} 31$ 
and CD34 values positively correlate with high values of $\mathrm{rCBV}$ within the tumours. A number of authors have stressed that $\mathrm{rCBV}$ values define the malignancy of gliomas and microvascular density within the tumours, i.e. the level of angiogenesis [2,7-9]. Others proved that $\mathrm{rCBV}$ above 1.75 is a recognized prognostic factor for WHO grade II gliomas and precedes rapid expansion of the tumour within the brain [12]. It is an additional prognostic factor on top of the fundamental one, i.e. histopathology of the tumour. Accordingly, both CD3 1 and CD34 expression levels and rCBV values comparably reflect the degree of neoangiogenesis within the tumour. Moreover, these values correlate with each other.

It has been proven as well that an $\mathrm{rCBV}$ value of 1.75 is an important threshold that stratifies patients into groups with higher and lower risk of an unfavourable outcome $[11,12]$. In our cohort of 53 patients, we found that patients with high values of CD31 expression within a low-grade glioma tissue had lower probability of overall survival. Accordingly, high density of microvessels within a WHO grade II glioma is a negative prognostic factor. On the other hand, no relationship between high levels of CD34 within the tumour's parenchyma and worse prognosis exists. It might arise, however, from a semi-quantitative method that we implemented for the number of patients with CD34 $3+$ and $2+$ expression levels in our cohort was comparable to the one with high expression of CD31 antigen.

\section{Conclusions}

1. Increased expression of CD31 and CD34 significantly correlates with higher values of $\mathrm{rCBV}$ within low-grade gliomas.

2. The relative CBV value of 1.75 in WHO grade II gliomas might be a threshold value for better or worse prognosis for these patients.

3. CD31 antigen expression is an important prognostic factor for overall survival of patients with low-grade brain gliomas.

\section{Disclosure}

Authors report no conflict of interest.

\section{References}

1. Pusztaszeri M.P., Seelentag W., Bosman F.T. Immunohistochemical expression of endothelial markers CD31, CD34, von Willebrand factor, and Fl-1 in normal human tissues. J Histochem Cytochem 2006; 54: 385-395.

2. Aroca F., Renaud W., Bartoli C., et al. Expression of PECAM1/CD31 isoforms in human brain gliomas. J Neurooncol 1999; 43: 19-25.

3. Khattab A.Z., Ahmed M.I., Fouad M.A., et al. Significance of p53 and CD31 in astrogliomas. Med Oncol 2009; 26: 86-92.

4. Assimakopoulou M., Sortiropoulou G., Maraziotis T., et al. Microvessel density in brain tumors. Anticancer Res 1997; 17: 4747-4753.

5. Santarelli J.G., Udani V., Jung Y.C., et al. Incorporation of bone marrow-derived Flk-1-expressing CD34+ cells in the endothelium vessels in the mouse brain. Neurosurgery 2006; 59: 374-382.

6. Aronen H.J., Gazit I.E, Louis D.N., et al. Cerebral blood volume maps of gliomas: comparison with tumor grade and histologic findings. Radiology 1994; 19: 41-51.

7. Shin J.H., Lee H.K., Kwun B.D., et al. Using relative cerebral blood flow and volume to evaluate the histopathological grade of cerebral gliomas: preliminary results. AJR Am J Roentgenol 2002; 179: 783-789.

8. Law M., Yang S., Wang H., et al. Glioma grading: sensitivity, specificity, and predictive values of perfusion MR imaging and proton $\mathrm{MR}$ spectroscopic imaging compared with conventional MR imaging. AJNR Am J Neuroradiol 2003; 24: 1989-1998.

9. Cha S., Johnson G., Wadghiri Y.Z., et al. Dynamic, contrastenhanced perfusion MRI in mouse gliomas: correlation with histopathology. Magn Reson Med 2003; 49: 848-855.

10. Saito T., Yamasaki F., Kajiwara Y., et al. Role of perfusion-weighted imaging at 3T in the histopathological differentiation between astrocytic and oligodendroglial tumors. Eur J Radiol 2012; 81: 1863-1869.

11. Majchrzak K., Kaspera W., Bobek-Billewicz B., et al. The assesment of prognostic factors in surgical treatment of low grade gliomas. A prospective study. Clin Neurol Neurosurg 2012; 114: 1135-1144.

12. Law M., Oh S., Johnson G., et al. Perfusion magnetic resonance imaging predicts patient outcome as an adjunct to histopathology: a second reference standard in the surgical and nonsurgical treatment of low-grade gliomas. Neurosurgery 2006; 58: 10991107.

13. Birner P., Piribauer M., Fischer I., et al. Vascular patterns in glioblastoma influence clinical outcome and variable expression of angiogenic proteins: evidence for distinct angiogenic subtypes. Brain Pathol 2003; 13: 133-143.

14. Lewelt A., Dziecioł J., Guzińska-Ustymowicz K., et al. Angiogenesis in gliomas. Folia Histochem Cytobiol 2008; 46: 69-72.

15. Yao Y., Kubota T., Takeuchi H., et al. Prognostic significance of microvessel density determined by an anti-CD105/endoglin monoclonal antibody in astrocytic tumors: comparison with an antiCD31 monoclonal antibody. Neuropathology 2005; 25: 201-206.

16. Wesseling P., Ruiter D., Burger P.C. Angiogenesis in brain tumors: pathobiological and clinical aspects. J Neurooncol 1997; 32: 253-265.

17. Iżycka E., Rzepko R., Borowska-Lehman J., et al. Angiogenesis in glioblastoma - analysis of intensity and relations to chosen clinical data. Folia Neuropathol 2003; 41: 15-21. 